\title{
The Effects of Using Infographics-based Learning on EFL Learners' Grammar Retention
}

\author{
Lam Ky Nhan ${ }^{1}$, Phuong Hoang Yen ${ }^{2}$ \\ ${ }^{1}$ Bachelor, School of Foreign Languages, Can Tho University, Vietnam \\ ${ }^{2}$ Doctor, School of Foreign Languages, Can Tho University, Vietnam
}

\begin{abstract}
In Vietnam, EFL learners have always been concerned about improving their grammar knowledge, and many efforts have been made to do so through various methods. Some studies suggest engaging students in their learning process and focusing their attention on untilizing multimedia and visualizations in form of infographics. However, little research has been conducted on the topic, and the current study is an attempt to find empirical evidence for such a suggestion in Vietnam context. This study was designed to examine the impact of infographics instruction on grammar learning. While the experimental group learned grammar with infographics instruction, the controlled group learned it with routine and traditional techniques. Finding reveals that infographics instruction was an effective instrument to help EFL learners learn English grammar.
\end{abstract}

Keywords - Infographics, grammar retention, visualizations

\section{INTRODUCTION}

Language plays an essential role in people's communication process. As for English, it is considered one of the most important languages all over the world. It helps communicating with foreigners at home and abroad. Accordingly, the English language is widely used in different fields, such as science, technology, computer services, politics, commerce and internet. Hence, many countries emphasize the importance of teaching English to their citizens. Richards (2001: 1) believes that "Second and foreign language teaching is one of the world's largest educational enterprise and millions of children and adult worldwide devote large amount of time and efforts to the task of mastering a new language".

There have been changes in the way language learning and teaching is carried out. Grammar is a set of rules that help organize words and sentences in a particular language. In English, the grammar of English is used to introduce and form sentences. Grammar is known as a set of rule that describe how words and group of word can be arranged to form sentence in a particular language. The grammar of English involves all the rules that govern the formation of English sentences, and that is exactly what learners of English want to know (Cowan, 2008). Despite the importance of grammar, many teachers still face various problems such as the improper use of traditional teaching methods and the lack of modern teaching aids. Regarding the significance of grammar in language learning, learner need to use effective and attractive ways rather than boring way to learn grammar. Among various type of instructional grammar technique graphic visualization of material are welcomed by both teacher and learner. Stokes (1997) believes that visualization continues to gain ground against traditional textbooks and it helps individuals to have greater transparency in previously unintelligible data. Hoffler and Leutner (2011) state that "in recent year, the role of individual difference in learning with visual representation has been more and more focused on" (p. 209).

Through the years, there have been a limited number of studies that investigated the effectiveness of infographics in promoting language learning. This paper aims to investigate the effectiveness of infographics instruction on EFL students. Although the positive effect of infographics on knowledge is indispensable, "there is a lack of research to examine what learner and instructional variable can infographics influence student learning especially in academic settings" (Lim \& Morris, 2009, p. 283).

This study sought to analyze the effect of infographic on EFL learner grammar retention. The following research question was posed: "To what extent does the use of Infographic-based learning affect students' grammar retention?". 
DOI: $\underline{10.51386 / 25815946 / \mathrm{ijsms}-\mathrm{v} 4 \mathrm{i} 4 \mathrm{p} 124}$

\section{LITERATURE REVIEW}

\subsection{Infographic-based learning}

The word "infographic" consists of the words "info" and "graphic" and it is shortened from the expression "information graphic". In general, the infographic is visual presentations of data, information, and knowledge.

An infographic is an arrangement of texts and images such as drawings and charts, combined with the use of color and white space to convey information visually. This visual demonstration of concept and data can potentially help the viewer to grasp information more readily (Janalta Interactive Inc, 2014). Although infographics are not new, in recent years, they are being used more frequently in educational contexts to convey messages, relate numerical data, illustrate important concepts, and promote visual literacy skills in learners (Krauss, 2012).

One of the most commonly used visual literacy media is infographic. According to Ferreira (2014), an infographic or information graphic is a type of picture that elaborates data with design which can help individuals and organizations concisely communicate messages to their audience. Mohd Noh et al. (2014) stated that the higher learning institutions should implement infographic in the learning process.

Infographics can be used to serve different educational purposes. Since comprehensive information can be presented through infographics, they can be used for different purposes such as showing the relationship between different concepts, transferring processes and events, presentation of the content of the course and summarizing the subjects learnt (Meeusah and Tangkijviwat, 2013).

Because of these outstanding feature, infographic may be a promising technique for instruction and could serve a variety of purpose. Lamb and Johnson (2014) proposed five uses for infographics:
a. organizing ideas and coherent manners in a useful way
b. illustrating biographical, scientific, art and design, historical, and social studies concepts in a visual way
c. comparing information in an effective way
d. making data meaningful by providing analogies, examples, and themes; plain data can be transformed into meaningful information
e. telling a story to convey the idea with visual and word in an exciting way rather than using only words

When the persistence of visual materials on the student is examined, a well-prepared infographic is likely to make a difference and to gain importance in the field of education (Borucu, 2015). There are several advantages of infographics in education such as reminding of existing information in normal or distance education, transferring processes and events, presentation of course content, summarizing learned information, showing relationships between concepts (Meeusah \& Tangkijviwat, 2013). Another point is that infographics can help a person to 26 remember more than $70 \%$ of the data that they have been seen, averagely (Gaille, 2016).

\subsection{Grammar teaching}

Grammar is as the way language manipulates and combines words (or bits of words) in order to form longer units of meaning (Ur, 1996). This definition is quite close to the common understanding of what grammar is. The main difference is that it tells us how the rules of language actually work - they arrange and shape words. Nevertheless, knowing what these rules do is not a very motivating factor alone. Crystal (2004) says, Grammar is the structural foundation of our ability to express ourselves. The more we are aware of how it works, the more we can monitor the meaning and effectiveness of the way we and others use language. It can help foster precision, detect ambiguity, and exploit the richness of expression available in English.

Grammar can be defined as the science that determines the rules of a language examining its sound, form and sentence structure (Turkce Sozluk, 2009); the information of structural rules in the functioning of the language (Imer, Kocaman \& Ozsoy, 2013); and the field of science that examines the sounds, word types and their structures, their arrangement and functions in the sentences and also the rules concerning their conjugation (Erdem \& Celik, 2011). Without teaching grammar, which enables students to discover the nature of the 
DOI: $\underline{10.51386 / 25815946 / \mathrm{ijsms}-\mathrm{v} 4 \mathrm{i} 4 \mathrm{p} 124}$

Volume: 4 Issue: 4

July to August 2021

https://www.ijsmsjournal.org

language through patterns that make what is said, read and heard comprehensible; the language will become a batch of words (Azar, 2007). By means of grammar rules the individual can use the language with its all components however s/he likes.

\subsection{Retention}

\subsubsection{Definitions of retention}

Schmidt and Bjork (1992) argue that learning is an imperfect indicator of later performance, and that learning and retention should consequently be considered together. It is therefore important to understand how acquired knowledge and skills are retained and should be maintained in the longer term. In addition, from the Oxford Advanced Learner's Dictionary, retention is basically defined as the ability to remember things.

According to Srinever (2003), retention is the mental capicity to store infomation. The term "retention" usually refers to consicous process which may invole rote learning, practice and associative learning.

\subsubsection{Classifications of retention}

Retention is classified into three types: sensory memory, long-term memory and short-term memory (Atkinson \& Shiffrin, 1968).

Sensory memory in which stimuli can be entered into the sensory stores regardless of whether or not the subject is paying attention to that source; that is, sensory stores are "preattentive" (Neisser, 1967). The input is represented in a rather literal form and can be overwritten by further inputs in the same modality (Neisser, 1967; Crowder \& Morton, 1969). Further features which distinguish the sensory registers from later stores are the modality-specific nature and moderately large capacity of sensory stores and the transience of their contents.

Short-term memory is related to the primary memory of James (1890) and is a term that Broadbent (1958) and Atkinson and Shiffrin (1968) used in slightly different ways. It is possible that not every temporarily accessible idea is, or even was, in conscious awareness. For example, by this conception, if you are speaking to a person with a foreign accent and inadvertently alter your speech to match the foreign speaker's accent, you are influenced by what was until that point an unconscious (and therefore uncontrollable) aspect of your short-term memory.

Long-term memory is a vast store of knowledge and a record of prior events, and it exists according to all theoretical views; it would be difficult to deny that each normal person has at his or her command a rich, although not flawless or complete, set of long-term memories. Conversely, manipulations that influence processing at a structural level should have transitory, but no long-term, effects. Modality differences (Murdock, 1966) provide a clear example. Finally, long-term recall should be facilitated by manipulations which induce deeper or more elaborative processing.

Information passes from store to store in a linear way, and has been described as an information processing model (like a computer) with an input, process and output. Information is detected by the sense organs and enters the sensory memory. If attended to this information enters the short term memory.

Information from the short-term memory is transferred to the long-term memory only if that information is rehearsed (i.e. repeated).

If maintenance rehearsal (repetition) does not occur, then information is forgotten, and lost from short term memory through the processes of displacement or decay. 
DOI: $\underline{10.51386 / 25815946 / \mathrm{ijsms}-\mathrm{v} 4 \mathrm{i} 4 \mathrm{p} 124}$

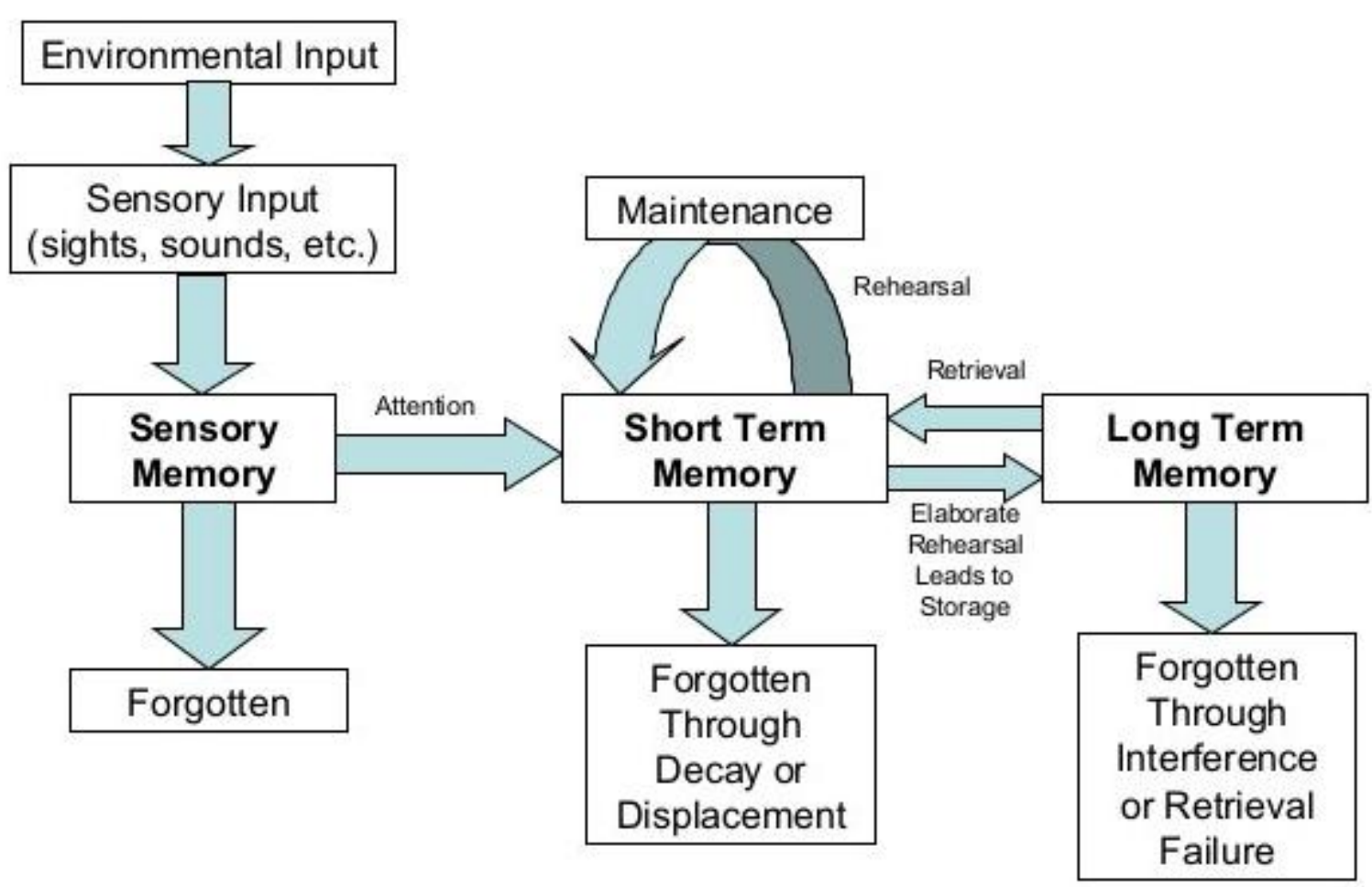

Figure 1: Multistore model of memory (Atkinson \& Shiffrin, 1968)

\section{III.METHODOLOGY}

\subsection{Research design}

The current study was designed as experimental research with a two-group pre-test and post-test design. According to Gay and Airasian (2000), an experimental research is aimed at investigating the impact and the effectiveness of the treatment. In this experimental research the implementation of the use of Infographic in learning Grammar lessons (the independent variable) was monitored, and the students' motivation in learning Grammar (the dependent variable) was measured. In order to measure whether a treatment has had an effect or whether one treatment is more effective than another, Cohen, Marion, and Morrison (2000), Fraenkel and Wallen (2000) argue that an experimental study should be carried out with two groups of participants: an experimental group who receives the treatment and a control group who does not receive the treatment. The control group is crucially important for it enables the researcher to compare the outcomes of the two groups.

In particular, the experimental study is conducted in a two-group pre-test and post-test design as well as a delayed post-test in a six-week period. Students both in the control and experimental groups learn the same content of the course as well as the same teacher-researcher during the six-week experiment. However, the only difference was that the experimental group was required to receive the Infographic-based learning instructions while the control group received the conventional learning instructions.

\subsection{Participants}

\subsubsection{Teacher}

The researcher was in charge of instructing lessons to both experimental group and control group.

\subsubsection{Students}

For the purpose of the present study, a total of 60 elementary adolescent learners including $36(60 \%)$ males and $24(40 \%)$ females of English center in Soc Trang city participated in the study. Most of them were 
DOI: $\underline{10.51386 / 25815946 / \mathrm{ijsms}-\mathrm{v} 4 \mathrm{i} 4 \mathrm{p} 124}$

students from a high school located in Soc Trang city with the age from 17 to 18 . Based on the final results of the previous school year, their knowledge was assumed to be at pre-intermediate level. These students had at least seven years of English learning experience. The level they study in that English center is basic and their grammar is not good, so they are invited to take part in this study. Moreover grammar is their very important knowledge because it was the focus in the school curriculum. They were also informed of Infographic-based's objectives as well as the benefits that they might gain if they join in the course.

The participants were conveniently assigned into two groups, so I randomly took one for the control group and the other, the experimental one. They were required to complete a pre-test, a post-test and a delay post-test in the study process.

Table I:

THE BACKGROUND INFORMATION OF THE TWO GROUPS

\begin{tabular}{|c|c|c|c|}
\hline Conditions & \multirow{2}{*}{ Number of participants } & \multicolumn{2}{|c|}{ Gender } \\
\cline { 3 - 4 } & & Males & Females \\
\hline Controlled group & 30 & 17 & 13 \\
\hline Experimental group & 30 & 19 & 11 \\
\hline
\end{tabular}

\subsection{Materials}

Tieng Anh 11 (textbook and workbook) published by the Ministry of Education and Training as well as the course book 'Destination B1 Grammar and Vocabulary' (Malcolm Mann) was selected to be the primary text book for participants to study during the course. The book can be supposed to be relevant to the level of proficiency of the learners as it was designed to assist the learners achieve the language objectives at the end of the course. Besides, supplementary materials of grammar lessons were adapted and modified from the grammar book "Life" published by John Hughes. The supplementary materials were designed carefully according to the learners' level of proficiency.

\subsection{Research instruments}

\subsubsection{Describing the tests}

In the current study, achievement tests (a pre-test, a post-test and a delayed post-test) were chosen for quantitatively measuring students' grammar ability. The achievement tests for pre-test, post-test a delayed posttest were adapted from Tieng Anh 11 (textbook and workbook) published by the Ministry of Education and Training as well as the course book 'Destination B1 Grammar and Vocabulary' (Malcolm Mann). Ellis (1997), Larsen-Freeman and Long (1991), Bachman (1990) stated that what students have learnt should be tested, and the test tasks should be appropriate to their target language use situations. It is therefore, believed that these achievement tests will measure students' grammar ability.

To establish the test's validity and reliability, Hughes (1989) suggested that the test should be designed based on what its purpose is, who the test aims at, what content is to be covered, what methods are to be used, how it marked, and then a detail set of specification for each section of the test set out.

The achievement tests were paper-and-pencil tests consisting of 21 items including 3 parts corresponding with 4 tasks such as multiple choice completion task, error recognition task and sentence transformation task.

The first part began with the multiple choice completion focusing on the ability to complete sentences using Relative Clauses and Cleft Sentences. The second part was the error recognition task. It was designed with the aim to recognize the errors relating to Relative Clauses and Cleft Sentences. The last one was the sentence transformation task. This task aimed to test students' ability to write a sentence equivalent in meaning to one that was given.

\subsubsection{Validating and piloting the tests}

After designing the pre-test, post-test and the delayed post-test, they were checked by the researcher's supervisor. The researcher also had two other experienced English teachers and two collegues to check the 
DOI: $\underline{10.51386 / 25815946 / \mathrm{ijsms}-\mathrm{v} 4 \mathrm{i} 4 \mathrm{p} 124}$

consistency of the test format, instruction and the number of the items and the content to ensure that the participants would get no problems with understanding these tests.

\subsubsection{Scoring criteria of the tests}

Hughes (1989) maintains that scorer reliability is of close relationship with test reliability. If the scoring of a test is not reliable, then the test results cannot be reliable either. For this reason, after the tests were constructed, the researcher designed criteria for scoring them. Particularly, the whole score of the test was 10 marks including 3 marks for part 1; 2,5 marks for part 2, and 4,5 for part 3. To score the test, the researcher chose different scoring methods for the first two parts and the rest of the parts.

Regarding scoring citeria for part 1 and part 2, the researcher used the method of right/wrong scoring for all items. A test-taker received a score of ' 0 ' for his/her wrong response and ' 0.3 ' for a correct response. Generally, each repsonse was scored based on a single criterion for correctness. In short, the parts were scored objectively, where the researcher failed to have to make any jugment in determining if the answers were correct.

However, with part 3, partial credit scoring was used. The range was from no credit ' 0 ' to full credit with a level of partial credit in between because test-takers might give a number of different answers. Therefore, a test-taker got full credit ' 0.5 ' with his/her response.

\section{IV.FINDINGS}

This section presents the findings of the study regard to students' Grammar performance before and after the intervention.

Three Grammar tests selected from achievement tests for students at eleventh grade were used to measure participants' achievement in English grammar language. Three tests were nearly identical in terms of structure and difficulty. Scoring for each is ranked from zero as the minimum to ten as the maximum. Scores were transferred to SPSS 20.0 for data analysis.

\subsection{Participants' Grammar retention within the two groups before and after the intervention.}

In order to identify students' changes in Grammar retention, the General Linear Model test was carried out. Initially, the result of control group's pre-test, post-test, and delayed post-test were collected and analyzed. With $\mathrm{p}=0.00$, it is confident enough to conclude that the pre-test's mean score and the post-test's mean score as well as the delayed post-test's mean score are different. Then, the Descriptive Statistic Test was performed to identify mean score of each test.

Table II:

Mean difference of students' grammar retention within control group

\begin{tabular}{llllllc}
\hline Group & \multicolumn{1}{c}{ Tests } & N & Min. & Max. & Mean & $\begin{array}{c}\text { Std. } \\
\text { Deviation }\end{array}$ \\
\hline \multirow{3}{*}{ Control } & Pre-test & 30 & 3.00 & 7.70 & 4.78 & 1.23 \\
& Post-test & 30 & 5.00 & 8.70 & 6.40 & .96 \\
& Delayed post-test & 30 & 4.50 & 8.00 & 6.01 & .94 \\
\hline
\end{tabular}

As can be seen from Table II, among the statistics, the results showed the difference of means in the pre-test, post-test and delayed post-test $(\mathrm{M}$ pre=4.78; $\mathrm{SD}=1.23, \mathrm{M}$ post=6.4; $\mathrm{SD}=0.96, \mathrm{M}$ delay=6.01; $\mathrm{SD}=0.94)$ $(\mathrm{F}=100.81, \mathrm{df}=1, \mathrm{p}=0.00)$. The mean score of the post-test was higher than that of the pre-test. Although the mean of the delayed post-test $(\mathrm{M}=6.01 ; \mathrm{SD}=0.94)$ was lower than the mean of post-test, it was higher than the mean of the pre-test. It can be concluded that after eight weeks of intervention, students' Grammar retention of control group was slighltly improved.

Subsequently, the General Linear Model test was employed to identify the difference of mean score of experimental group's pret-est, post-test and delayed post-test $(\mathrm{p}=0.00)$ led to a conclusion that it was fully confident that the vocabulary retention of the experimental group was different at pre-test, post-test and delayed post-test. Later, the mean scores of the pre-test, post-test and delayed post-test were clarified by Descriptive Statistic Test. 
DOI: $\underline{10.51386 / 25815946 / \mathrm{ijsms}-\mathrm{v} 4 \mathrm{i} 4 \mathrm{p} 124}$

Table III:

Mean difference of students' grammar retention within experimental group

\begin{tabular}{cllcccc}
\hline Group & \multicolumn{1}{c}{ Tests } & N & Min. & Max. & Mean & $\begin{array}{c}\text { Std. } \\
\text { Deviation }\end{array}$ \\
\hline \multirow{3}{*}{ Experimental } & Pre-test & 30 & 3.50 & 8.50 & 5.26 & 1.55 \\
& Post-test & 30 & 5.80 & 9.40 & 7.59 & 1.00 \\
& Delayed post-test & 30 & 5.00 & 8.70 & 7.32 & 1.06 \\
\hline
\end{tabular}

The mean score of the pre-test was different from post-test's mean score. (M pre= 5.26; $\mathrm{SD}=1.55, \mathrm{M}$ post $=7.59 ; \mathrm{SD}=1.00)(\mathrm{F}=108.42, \mathrm{df}=1, \mathrm{p}=0.00)$. The result indicates that the mean of the post-test was higher than that of the pre-test. In addition, the mean of the delayed post-test $(\mathrm{M}=7.32 ; \mathrm{SD}=1.06)$ was lower than that of the post-test but it was still higher than that of the pre-test. After the study, the Grammar retention of experimental group was remarkably increased.

\subsection{Participants' Grammar retention between the two groups before and after the intervention}

After collecting data from Grammar tests, descriptive statistics tests were also conducted on students' grammar achievement to explore the minimum, the maximum, the means and the standard deviation of scores that each group obtained before and after the experiment. Table IV was a summary of the results from the descriptive statistics tests.

Table IV:

Descriptive statistics about students' grammar retention achievement

\begin{tabular}{ccccccc}
\hline Grammar tests & Conditions & N & Min. & Max. & Mean (M) & Std. Deviation \\
\hline Prettest & Control & 30 & 3.00 & 7.70 & 4.78 & 1.24 \\
& Experiment & 30 & 3.50 & 8.50 & 5.26 & 1.55 \\
Posttest & Control & 30 & 5.00 & 8.70 & 6.40 & 0.96 \\
& Experiment & 30 & 5.80 & 9.40 & 7.59 & 1.00 \\
Delayed posttest & Control & 30 & 4.50 & 8.00 & 6.01 & 0.94 \\
& Experiment & 30 & 5.00 & 8.70 & 7.32 & 1.06 \\
\hline
\end{tabular}

It can be clearly seen from Table IV that there were significant differences about the total mean scores for Grammar achievement between and within the two groups before and after the experiment. Both of the two groups obtained higher total mean scores after the experiment. In addition, the mean score of the experimental group $(M=7.59)$ was slightly higher than the control group $(M=6.40)$ after the experiment.

However, the evidence insufficiently supported that these differences were statistically significant. Ttests must continuously be conducted to examine the significance of the mean scores differences.

\section{Comparision of participants' Grammar retention between the two groups before the intervention}

As can be seen from Table IV, among the statistics, mean is a prominent factor in comparing the two groups. The means were nearly the same between control group $(M=4.78)$ and experimental group $(M=5.26)$, which proves that the students from the two groups were at an equal level at the beginning.

As can be calculated, 4.78 subtracted from 5.26, there was a small disparity of 0.48 between the two means, but the researcher wanted to carefully check whether the results were significant or not. Therefore, the researcher used an Independent samples t-tests to evaluate.

First, we should consider the Sig. value in Levene's Test for Equality of Variances. It was 0.125, which was significantly greater than the alpha value of 0.05 , so the variability in the two groups was not that markedly 
DOI: $\underline{10.51386 / 25815946 / \mathrm{ijsms}-\mathrm{v} 4 \mathrm{i} 4 \mathrm{p} 124}$

Volume: 4 Issue: 4

July to August 2021

https://www.ijsmsjournal.org

different. Therefore, we can use the results in Equal variances assumed in which the Sig. (2-tailed) was bigger than the alpha value of 0.05 , which meant there is no significant disparity between the two means. In general, this score indicates that participants in the two groups did not differ from each other in term of Grammar performance level. This results also matches the researcher's previous assumption that participants' Grammar performance between the two group is at the similar level before the treatment.

\section{Comparision of participants' Grammar retention between the two groups after the intervention}

Table IV also shows that after the study the mean score of participants' Grammar performance of the experimental group $(M=7.59)$ is greater than that of the control group $(M=6.40)$, which the number of the mean scores of the experimental group was 1.19 higher than that of the control group. Like in the pre-test, in the post-test the researcher scrutinized the Independent samples T-test to evaluate whether there was a statistically significant differences in Grammar performance between the two groups after the experiment.

The mean difference (MD = -1.19) in participants' Grammar performance between the two conditions after the study is statistically significant $(\mathrm{t}=-4.71, \mathrm{df}=58, \mathrm{p}=.00)$. This means that after the experimentation, participants' Grammar performance between the two conditions is significantly different: the post level of the experimental group is higher than that of the control group. Because of the difference in the means of the two groups after the treatment, the researcher can conclude that the experiment was effective. The students under the treatment had improved their Grammar performance.

A Paired Samples T-test was then run to check whether there was a significant difference between the result of the pre-test and post-test. The result revealed that there was a statistically significant difference between the pre-test and post-test $(\mathrm{df}=29$, Pfinal $=0.00<0.05)$. From that, the researcher can conclude that Infographic learning instructions had an influence on students' grammar retention. The students under the treatment improved their grammar retention.

Moreover, the data analysis from Table IV also revealed that the students' grammar retention between the two groups was different after the intervention. After six weeks of the intervention, the means of the posttest of both groups were highly improved (Mpost $=6.40$ for the control group, experimental Mpost $=7.59$ for the experimental group). In addition, there were relative decreases in the means of the delayed posttest of both groups (four weeks after intervention) (control Mpost $=6.01$, experimental Mpost $=7.32$ ). Figure 2 below presents the progress of both control group and experimental group.

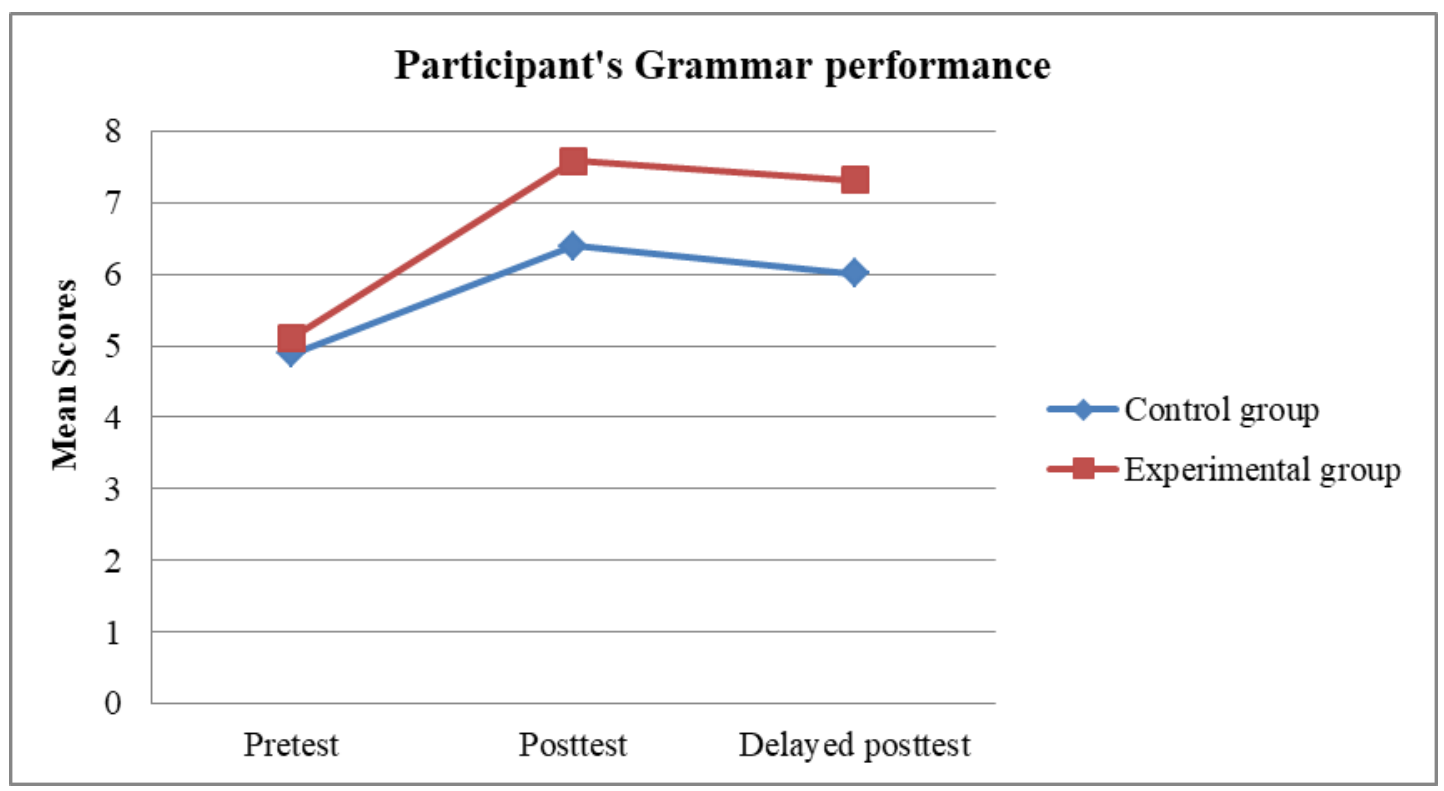

Figure 2: Summary of participant's Grammar retention performance before and after the study 
DOI: $\underline{10.51386 / 25815946 / \mathrm{ijsms}-\mathrm{v} 4 \mathrm{i} 4 \mathrm{p} 124}$

It could be clearly seen from Figure 2 that the mean score of control and experimental group before treatment are nearly the same which is known as 4.78 and 5.26 respectively. In contrast, after treatment, the mean score of control and experimental group is significantly different which is known as 6.40 and 7.59 respectively. That means, after the treatment, the mean score of the experimental group is 1.19 higher than that of the controlled group. Results inllustrated that the line of the mean score of the post-test of experimental group was growing up from 5.26 to 7.59 , which can be highlighted that there was an increase in students' Grammar retention performance after the intervention.

\section{DISCUSSION}

The researcher had observed the effects of Infographics in this study. This research was conducted by two groups. One of which was designated as an experimental group, and another as a control group. The experimental group received Infographic instructions, while the control group did not. Grammar performance participants who used infographics had positive effects on grammar retention after six weeks of testing. Moreover, the research questions were clearly answered by the findings.

Results of the study were consistent with the findings of many studies, such as Dr. Tamer Ibrahim and Dr. Ameerchund Maharaj (2019), Rezaei, N. (2015) who investigated the effect of using Infographic instructions on EFL learners' grammar retention. They found that using Infographic instructions could enhance EFL learners' grammar retention.

Also, the findings of the present study were in line with Sadeghi and Farzizadeh (2013) who investigated the vocabulary learning gains of beginner EFL learners using the application of visual aids in experimental group and the traditional technique of definition in controlled group. The results indicated the experimental group outperformed significantly better than the controlled group in the post-test.

The results of current study proved that teaching grammar items through using infographic instruction would lead to better comprehension among EFL learners. Infographics instruction increased the motivation of learner to improve their grammatical knowledge. In addition to the fact that infographic instruction was innovative for the participant of the study, it could provide opportunities for them to be more successful in their grammar learning.

\section{VI.CONCLUSION}

The present study was conducted to examine the impacts of using Infographic instructions on EFL students' Grammar retention. First, while teaching grammar, students were able to learn more easily by using infographics. Additionally, students were drawn to this learning resource due to their fondness for visuals. The students were engaged and motivated to practice grammar rules and complete the exercises, which they did with enthusiasm. Second, using Infographic as a teaching and learning tool can motivate learners to practice grammar and improve their level, according to the current study. An infographic-based program proved to be an effective and attractive tool for improving EFL grammar achievement based on the study's findings. Third, they also organized the infographics' information so that it was clear that they understood the main message.

In conclusion, the present study's findings may also have implications for learners in the future. Students can easily enjoy the learning process with infographic instructions because it provides opportunities for collaborative activities. They can then prepare themselves for the main tasks. As well, they may learn how to examine problems carefully, come up with solutions, select the best solution, cooperate with the other group members, assume responsibilities, share their knowledge and responsibilities, and develop the habit of working hard if their teacher praises their efforts.

\footnotetext{
About the Authors

Lam Ky Nhan earned his B.A in English Education from Can Tho University in 2018. He is a teacher of English at High school in Soc Trang, currently pursuing his Master's, with anticipated graduation in 2021. His teaching interests include teaching grammar and academic writing, teacher and learner motivation, testing and assessment.
} 
DOI: $\underline{10.51386 / 25815946 / \mathrm{ijsms}-\mathrm{v} 4 \mathrm{i} 4 \mathrm{p} 124}$

Phuong Hoang Yen is currently an English teacher at the School of Foreign Languages, Can Tho University, Vietnam. She carries studies on language teaching approaches, students' learning autonomy, self-regulated learning strategies and teachers' professional development. She published articles in different journals and is the editor of one book on formative assessment in language teaching.

\section{References}

[1] Atkinson, R.C. and Shiffrin, R.M. (1968) Human memory: a proposed system and its control processes. In: Spence K.W. and Spence J.T. (Eds.), The Psychology of Learning and Motivation: Advances in Research and Theory, Vol. 2. Academic Press, New York, pp. 89-195.

[2] Azar, B. (2007). Grammar-based teaching: A practitioner's perspective. TESL-EJ: Teaching English as a Second or Foreign Language. Volume 11, Number 2, September 2007.

[3] Bachman, L. F. 1990. Fundamental Considerations in Language Testing. Oxford: Oxford University Press.

[4] Borucu, A. (2015). Güzel Sanatlar Liselerinde Grafik Dersinin İşlenişinde İnfogragik’in, Öğrenme Yöntemine Katkısı. Süleyman Demirel Üniversitesi. Yüksek Lisans Tezi, Süleyman Demirel Üniversitesi, Isparta.

[5] Broadbent, D.E. (1958) Perception and Communication. Pergamon Press, New York.

[6] Cowan, R. (2008). Teachers grammar of English with answers. Cambridge: Cambridge University Press.

[7] Crystal, D.. (2004). Words And Deed. Available online at http://www.davidcrystal.com/DC_articles/Education2.pdf.

[8] Erdem, I. \& Celik, M. (2011). Dil bilgisi ogretim yontemi uzerine degerlendirmeler. Turkish Studies - International Periodical For The Language, Literature and History of Turkish or Turkic. Vol. 6/1 Winter. p.1030-1041.

[9] Fraenkel, J.R \& Wallen, N.E. (2000). How to Design and Evaluate Research in Education, New York, NY: Mc Grawhill Companies Inc.

[10] Gaille, B. (2016). 18 Pros and Cons of Infographics. Retrieved from https://brandongaille.com/18-pros-and-cons-of-infographics/

[11] Hoffler, T., \&Leutner, D. (2010). The role of spatial ability inlearning from instructional animations- Evidence for ability ascompensator hypothesis. Computers in Human Behavior, 4(2), 56-62.

[12] Hughes, A. 1989. Testing for language teachers. Cambridge: Cambridge University Press.

[13] Imer, K., Kocaman, A., Ozsoy, A. S. (2013). Dilbilim sozlugu. Istanbul, Bogazici Universitesi Yayinevi.

[14] James, W. (1890) The Principles of Psychology. Henry Holt, New York.

[15] Janalta Interactive Inc. (2014). Information graphic (infographic). Retrieved from http://www.techopedia.com/definition/27808/information-graphic-infographic

[16] Krashen, S. (1985). The Input Hypothesis: Issues and Implications. Harlow: Longman.

[17] Krashen, S. D. (1982). Principles and practice. New York: Pergamon Press.

[18] Krauss, J. (2012). More than words can say: Infographics. Learning and Leading with Technology, 39(5), 10-14.

[19] Lamb, A., \& Johnson, L. (2014). Infographics part 1: Invitations to Inquiry. Teacher Librarian, 41(4), 54-58, 63.

[20] Larsen-Freeman, D. (1986) .Techniques and principles in language teaching. Oxford: Oxford University Press

[21] Lim, D. H., \& Morris, M. L. (2009). Learner and Instructional Factors Influencing Learning Outcomes within a Blended Learning Environment. Educational Technology \& Society, 12(4), 282-293.

[22] Meeusah, N., \& Tangkijviwat, U. (2013). Effect of data set and hue an a content understanding of Infographic. http://www.repository.rmutt.ac.th/xmlui/handle/123456789/1263 (Access Date: 20.01.2015)

[23] Meeusah, N., \& Tangkijviwat, U. (2013). Effect of data set and hue on a content understanding of infographic. ACA2013 Thanyaburi:Blooming Color for Life, December 11-13,2013, 272-275.

[24] Mohd Noh, Mohd Amin \& Shamsudin, Wan Nur \& Amin Nudin, Anith \& Narimah, Nik \& Harun, Mohd. (2014). The Use of Infographics as a Tool for Facilitating Learning. 559-567. 10.1007/978-981-287- 332-3_57. 
DOI: $\underline{10.51386 / 25815946 / \mathrm{ijsms}-\mathrm{v} 4 \mathrm{i} 4 \mathrm{p} 124}$

Volume: 4 Issue: 4

July to August 2021

https://www.ijsmsjournal.org

[25] MURDOCK, B. B. JR. Visual and auditory stores in short-term memory. Quarterly Journal of Experimental Psychology, 1966, 18, 206-211.

[26] NEISSER, U. Cognitive psychology. New York: Appleton-Century-Crofts, 1967.

[27] Rezaei, N. (2015). The Impact of Infographics on Iranian EFL Learners' Grammar Learning. Journal of Applied Linguistics and Language Research,2(1), 78-85.

[28] Richards, C J (2001). Curriculum development in language teaching, CUP.UK: Cambridge university press.

[29] Sadeghi, K., \& Farzizadeh, B. (2013). The Effect of Visually-Supported Vocabulary Instruction on Beginner EFL Learners' Vocabulary Gain. MEXTESOL Journal, 37(1), 1-12.

[30] Schulten, K. (2010). Teaching with infographics: Places to start. Retrieved April 21, 2018, from http://learning.blogs.nytimes.com/2010/08/23/teaching-withinfographics-places- to-start/?_r=0

[31] Srinever, J. (2003). Teaching Grammar. Oxford: Oxford University Press.

[32] Stokes, D. (1997). Pasteur's quadrant: Basic science and technological innovation. Washington, DC: Brookings Institution Press.

[33] Tamer, I., \& Ameerchund, M. (2019). The impact of Infographics on Language Learning. IJCSNS International Journal of Computer Science and Network Security, 19(12), 47-60

[34] Turkce Sozluk. (2009). TDK s.529 Ur, Penny. 1996. A Course in Language Teaching: Practice and Theory. Cambridge: Cambridge University Press. 